\title{
A Comment on Katherine Mansfield’s A Dill Pickle
}

\author{
WANG Xiao-yan, LI Ze-ming \\ Changchun University, Changchun, China
}

\begin{abstract}
Katherine Mansfield is a world famous woman master of short stories in English literature. Her stories are sensitive revelations of human behaiour in quite ordinary situations, through which we can glimpse a powerful, and sometimes cruelly pessimistic view of life. A Dill Pickle is one of her short stories published in 1917, describing the encounter between a young woman and a young man who have been lovers six years ago and their lost love and changes over the years. Short as it is, it is really worth our carful analysis and appreciation. This paper will comment on this short story from the following two aspects: a commont on the theme of the story; a comment on the writing technique of the story. The paper conludes that romantic love is dependent upon circumstances and the convergence of certain character traits at a particular time.
\end{abstract}

Keywords: A Dill Pickle, Katherine Mansfield, theme, technique

\section{Introduction}

Katherine Mansfield, an outstanding woman master of short stories of 20th century English literature, was born in a middle-class family in New Zealand. Throughout her life, she led a wandering life in search of health and wrote under difficulties. And most of her works are from the recreation of her experineces with the theme of women's disillusion and loneliness. A Dill Pickle, completed in 1917, is one of her most significant masterpieces and it is based on her own experience. In her early life, she studied music and fell in love and married a violin player, but separated later on. A year later, she met another young man whom she thought she would marry. They shared the plan to travel in Russia and arranged their marriage while his family opposed to their marriage because Katherine Mansfield is a widow. The young man was forced to end their relation. Soon after she found herself in pregnant, and wrote to the young man in hope that he would come to see her, however, in vain. Alone and lonely, she went to Germany and the child was aborted. Then six years later, they met with each other in a restaurant.

The story just began with the meeting of two lovers who parted six years ago in a restaurant. Vera, the heroine, separated with the man because she found the man was not suitable for her. The man, whose name we do not know, after possible success and a traveling around the places they used to plan, met Vera and talked about their past and his current gorgeous life, ignoring her current miserable life. During the conversation, Vera, who did not speak much, was very sensitive inside while the man, the hero, who was good at using the flowery

\footnotetext{
* Acknowledgements: This paper is a part of the results of the research programs the author has participated, The Study of English Post Modern Feminism Metafictions, No. 2015220.

WANG Xiao-yan, Master, Professor, School of Foreign Languages, Changchun University.

LI Ze-ming, Master, Lecturer, College for Internationl Students, Changchun University.
} 
words, seemed so insensitive and self-centered, and interrupted her all the time. In the end, while the man was still indulge in his audacity claim, "It simply was that we were such egoists, so self-engrossed, so wrapped up in ourselves that we hadn't a corner in our hearts for anybody else” (YANG, 1996, p. 48). Vera, at this moment, had deep recognition of the man, she felt despaired and left. The man, "sat there, thunder-struck, astonished beyond words" (YANG, 1996, p. 48).

Very short as the story is, it is the typical style of Mansfield who writes in an impressionistic style, focusses on psychological conflicts, and articulates the characters. In the short story, there is no complicated plot, the hero and heroine's characters are vividly depicted through their dialogues and the heroine's psychological changes when they meet each other after six years in a raustrant. The simple story proves she is skillful in depicting the slice of life.

\section{A Comment on the Theme of the Story}

Sensitivity and insensitivity are the theme of the short story and it is repeated throughout the story. At the very beginning of the story, when, upon entering the restaurant, he doesn't even recognize her, “And then, after six years, she saw him again... He must have felt that shock of recognition in her for he looked up and met her eyes. Incredible! He didn’t know her” (YANG, 1996, p. 42). A sharp contrast is making here. At first glance Vera recognizes him and smiles because she runs into an old friend, while the man frowns because he can not recall where he met the women before. After recognizing each other, the man is so insensitive that he praises Vera by saying that she looked so well. In fact Vera is neither feeling well at that time, nor can she bear the cold weather, and she is beginning to feel the effect of her growing age. Quite likely she is sick at that moment. And when, after their first few words, he resorts to his long-term habit of interrupting her, which exasperated her six years ago, without mentioning her health at all. Here we get our first glimpses of his self-invlvement.

His insensitivy also lies in his strong egotism which prevents him from seeing how greatly their lives have diverged in the six years since they parted. During those years, he has done, by himself, all the things they dreamed of doing together-travelling to Spain, Corsica, Siberia, Russia, and Egypt. By contrast, she, in the meantime, has experienced a deterioration in her financial situation; she has even had to sell her piano, which she loves to play, but she told a lie to him by saying that she had no time to play. However, he pays to attention to Vera's plight and her sensitive to natural beauty as well as to music and art, and continues to talk about himself and his travels, especially his travel to Russian, which is Vera's long-cherished wish. At this time the man also talks about the booatman's song Vera used to play, the dill picke...For those, Vera can only enjoy in her mind. Now we have further understanding of Vera and the man. We seems to know why Vera left him six years ago.

While he is insensitive to her thoughts and feelings, she is sharply aware of his thoughts and feelings, more sensitive than he himself is. She even remembers the details of his boyhood better than he does, even the name of his dog. Vera does not give up her hope to the man until he goes so far as to make light of that very critical point in her life when she wrote to him breaking off their relationship. "I found the letter the other day, and I couldn't help laughing as I read it” (YANG, 1996, p. 47). He trivializes the letter, and thereby their break-up when he continues: "It was so clever..." (YANG, 1996, p. 47). And he ends his comments with “...such a true picture of me” (YANG, 1996, p. 47). Vera is obviously hurt, because the man has practically 
forgotten everything about their past love. The man also said that he had had to take such a leap to that time, showing again that he had ceased to care about her. What hurts her most, however, is probably the way he described when he read her last letter. He practically treats the whole thing of love as a joke.

At the end, he has the audacity to claim that they were both egotistical, both self-engrossed. This statement unequivocally proves to her the extent of his egotism, which blinds him to the fact that it is he, not both of them, who has this problem. The author makes it clear that she is making precisely this point when she describes his way of speaking at that monment as "naive and hearty".

The man's total insensitivity of Vera's thoughts and feeling is once agian revealed in the line of the story when she leaves. The author describes his reaction: "He sat there, thunder-struck, astonished beyond words" (YANG, 1996, p. 48). Words failed him. He could not understand why she wanted to leave. But we reader see clearly the true nature of the man.

\section{A Comment on the Writing Technique of the Story}

Mansfield abandons traditional structure of a novel which follows the time sequence. Instead she uses modern way of writing which mingles past memories with reality pictures by using the technique of inner world description.

At one scene in the story, the writer describes the joy of their encounter after a long separation, they were drinking something while the man was recalling their beautiful past experience, again ignoring Vera's feeling. When the man is indulged happily and brightly in his recollection of their first afternoon they spent together at Kew Gardens. Vera's inner world is woken. What remained in her mind of that particular afternoon is in fact an absurd scene, with the man's childish and ridiculous behavior. But as time goes by, that memory fades. What remained is a really wonderful, sunny afternoon. As her memory unfolds, she remembers that he even expressed his love to her at that time. This inner description indicates that they were once in love, and Vera is in hesitation whether she should accept his love. From this inner description we feel what Vera feels and wish what Vera wishes. We really hope that this recalling would bring a good result to both of them.

Another important scene is when the man was imbued with the fantasy of what he has done in those six years, in particular, his travelling to Russia. "she felt the strange beast that had slumbered so long within her bosom stir, stretch itself, yawn, prick up its ears, and suddenly bound to its feet, and fix its longing, hungry stare upon those far away places" (YANG, 1996, p. 45). Here the author compares her dream to "the strange beast that had slumbered so long within her boson”. We can also see traveling to Russia and other countries with the man she loved is her long-cherished wish. It has been hidden deep for quite a long time because it is impossible to realize it six years ago. But now, gradually the beast stirs, stretches itself, yawns, pricks up its ears, and suddenly bound to her its feet—-the beast revives. The "beast" is her hidden dream and now this old wish seems to be suddenly awakened. Vera's inner voice is longing for those travel life with him and longing for his true love. When the man continues to talk about Russia, Vera seems to be sitting on the grass with the young man, listening to the boatman's song, and seeing the boat floating on the darkening river with melancholy trees on either side. They are having a picnic, with their supper in a cloth on his knees. The man is asking her to have dill pickle. Even though she does not know exactly what a dill is, "She saw the greenish glass jar with a red chili like a parrot's beak” (YANG, 1996, p. 46). This inner description is the climax of the 
story. What was awakened is not only the dream of traveling, but also the love between them. What a beautiful scene! We really wish that Vera's dream would come true and they two can live happily together!

Yet, when the man treats her last letter about their love as a joke, Vera is obviously hurt. She wanted to leave. At this moment the man tried to urge her to stay, by saying a lot of flowery words. Vera was so moved that she seemed to have drunk something, and the "that strange beast in her bosom began to purr" (YANG, 1996, p. 48). She has just heard something refreshing which made her feel good. And her long-buried love for the man seems to wake up again. Here the author describes her inner voices by the use of interior monologues. "What have I done! How dare I to throw away my happiness like this! This is the only man who has ever understood me. Is it too late? Could it be too late?” (YANG, 1996, p. 48). From the above inner description we realize that she has the opportunity to renew their relationship. She is alone and lonely, and he is successful and financially able to help her realize her dreams. Yet, she leaves, because she recognizes that he is still insensitive and self-engrossed. In fact, he has not chaged at all. She won't be happy, if they were together.

\section{Conclusion}

A Dill Pickle is a very short and simple story. It is the typical style of Mansfield which has no principal contradiction and life confliction in the novel. The author just chooses a slice of life, a fragment of life from the angle that common people will usually neglect, and gradually unfolds the character's inner world to make this kind of life scene produce colorful significances.

The young man and Vera's love affair is not uncommon, yet, the author writes in an impressionistic style. First of all she focusses on the sharp contrast between them: the man's insesitivity and Vera's sensitivity. Through the disharmony between their ways of communication, it can be inferred the divergence of their love and the shortcomings in their personality. Mansfield is very skillful in describing her characters' psychological conflicts, and inner activities from which we can understand the theme even better. We take sympathy for Vera, yet, we welcome her decision. The man is as same as he was six years ago. Meanwhile we take pity that the man is too egoist to leave a place for others in his heart. The saddest thing is that he is not aware of it in the end.

From Mansfield's life story, we know she suffers in her love affairs. A Dill Pickle reveals the loneliness and disillusionment of the female in reality at that time as well as the author's passive, doubtful attitude towards love. Mansfield is hopeless that there would be no happy ending for the man and the woman, since they have different attitude towards love because of their different character traits. The story artfully and subtlety points up Vera's sensitivity and the man’ insensitivity to others—-their feelings, attitudes, and inner motivations.

\section{References}

GAO, C. Y. (2007). From loss to wakening. Science, 31, 472-473.

GUI, Y. Q. (1985). Selected reading in English and American literature. Beijing: Translation Company Press.

HE, D. L. (2011). Katherine Mansfield: A special feminist-by a close reading of a dill pickle. Overseas English, 8, 34-37.

LIU, B. S. (2001). A short history of English literature. Zhengzhou: Henan People’s Publishing House.

Mansfield, K. (2007). The garden party and other stories. Whitefish: Kessinger Publishing LLC.

Mansfield, K. (1962). Bliss and other stories. London: Penguin Books.

SU, Q. F. (2002) Katherine Mansfield and her short story. Journal of Fujian Education Institute, 4, 76-77.

WANG, L. N. (2013). Close reading on Katherine Mansfield’ a dill pickle. Overseas English, 8, 201-203. 
YANG, L. M. (1996). College English book 4. Beijing: Foreign Language Teaching and Research Press.

YANG, L. M. (1996). Teachers' book of college English. Beijing: Foreign Language Teaching and Research Press. ZHANG, B. X. (2005). A course book of English literature. Wuhan: Wuhan University Publishing House. 